\title{
Phenolic Compounds, Antioxidant and Antimicrobial Activities of Some Plants Belonging to Family Apiaceae
}

Fatma A. Ahmed ${ }^{1}$, Dina. M. Baraka ${ }^{2}$, M. Abdel-Mawgoud ${ }^{1}$, Heba. S. Essawy ${ }^{2}$, Hoda. F. Elbadawy $^{2}$

${ }^{1}$ Medicinal and Aromatic Plants Department, Desert Research Center, Cairo, Egypt

${ }^{2}$ Botany and Microbiology, Dept., Faculty of science, Benha Univ., Benha, Egypt

E-Mail: hoda.ghoniem@fsc.bu.edu.eg

\begin{abstract}
Apiaceae is one of the most important families containing a large variety of plants. Members of this family are well known for their analgesic, antibacterial, antiviral, and anticoagulant effects. This study described the HPLC-identification of phenolic compounds in four plants belonging to family Apiaceae, i.e. Anethum graveolens, Petroselinum crispum, Deverra tortuosa and Daucus syrticus. Catechin, chlorogenic acid, and rutin were found in all $70 \%$ ethanolic extracts of plants, according to HPLC analysis. Except for Anethum graveolens, all plants contained apigenin. Caffeic acid was exclusively found in Deverra tortuosa. All extracts were to be devoid of gallic acid and hesperidin. Quercetin was found in Daucus syrticus and Anethum graveolens, while kampferol was found only in Daucus syrticus, and ellagic acid was found in Daucus syrticus and Petroselinum crispum. The four extracts had no effect on Aspergillus fumigates and Staphylococcus aureus, while the extract of Anethum graveolens had no effect on Proteus vulgaris. The extracts of Deverra tortuosa and Anethum graveolens demonstrated the best effects on Bacillus subtilis and Candida albicans, respectively. Petroselinum crispum produced also the best effect on Bacillus subtilis. The highest levels of antioxidant activities were observed for Deverra tortuosa and Daucus syrticus.
\end{abstract}

Keywords: Apiaceae, Anethum graveolens, Petroselinum crispum, Deverra tortuosa; Daucus syrticus, Phenolic, Antioxidant; Antimicrobial.

\section{Introduction}

Apiaceae is one of the botanical families containing a large variety of plants. Members of family Apiaceae are well known for several biological activities, such as analgesic, antibacterial, antiviral, and anticoagulant effects [1]. This family is rich in phytochemicals and secondary metabolites such as terpenoids, triterpenoid, saponins, flavonoids, coumarins, polyacetylenes, and steroids.

Anethum graveolens L., commonly known as dill, is an annual aromatic herb belonging to family Apiaceae originated from Mediterranean and West Asia, being widely cultivated in Pakistan, India, Afghanistan, Middle East, Russia, Iran, Egypt, Thailand, Africa, China, USA, Canada, Hungary, Bulgaria, Turkey and Uzbekistan [2]. It has been used as a spice and as a medicine [3]. Dill is an important aromatic herb, used for flavoring of various foods, such as salads, sauces, soups, and sea food [4]. The plant showed antimicrobial, antihyperlipidemic and antihypercholesterolemic activities [5-7], also the plant has diuretic, carminative, stimulant and hypolipidemic activities, and it could be used as a cardioprotective, antibacterial, and antispasmodic agent $[8,9]$. A. graveolens is used in traditional medicine for treatment of digestive disorders, bad breath, lactation motivation, and also as a hypolipidemic agent.

Petroselinum crispum Mill. (Parsley) has been widely cultivated in the tropic, sub-tropic and temperate regions [10]. It has been used as a medicinal plant for ailments and complaints of the gastro-intestinal tract, as well as the kidney and lower urinary tract, and for stimulating digestion [11]. Furthermore, it is used for treatment of dyspepsia, cystitis, dysmenorrhea, functional amenorrhea and myalgia [12]. P. crispum is used for management of menstrual disorders, and as emmenagogue, galactagogue and stomachic agent. It is also applied externally against head lice [12].

Deverra tortuosa (Desf.) DC. is strongly aromatic shrub of $30-80 \mathrm{~cm}$ height. The plant has bluish greenbranched stem with caduceus leaves. D. tortuosa grows naturally in almost all the phytogeographical regions of Egypt especially desert wadis, sandy and stony plains [13]. The plant is used traditionally in Egypt as a carminative, diuretic, and analgesic agent, it is also used to relief stomach pain and against intestinal parasites [14]. Moreover, it is used as an anti-asthmatic agent, against scorpion stings [15], and intestinal parasites, when blood is excreted in the urine or when coughing blood, and for the regulation of menstruation [16].

Daucus syrticus Murb. is a herbaceous plant, mostly distributed in Europe, Africa and West Asia, and a few in North America and Australia [17]. The ethnobotanical uses of plants of this genus include applications in treatment of cough, diarrhea, dysentery, cancer, malaria and tumors, and as an antiseptic, abortifacient, aphrodisiac, carminative, stimulant, stomachic and tonic agent [18]. The pharmacological studies of D. carota have demonstrated its antibacterial, antifungal [19], anthelmintic, hepatoprotective [20] and cytotoxic activities [21].

This study aimed at investigating the chemical constituents, antioxidant and antimicrobial activities of these plants of family Apiaceae collected from the field in order to evaluate their potential uses and medicinal properties. 


\section{Material and Methods}

\section{Plant Collection and Preparation}

The fresh aerial parts (stem and leaves) of plants were collected during the period of investigation (2019). Cultivated plants (A. graveolens \& P. crispum) were collected from Beni Seuif and wild plants (D. tortuosa and Daucus syrticus) were collected from Matrouh. Plant specimens were identified by Dr. Omran Ghaly, and deposited in Herbarium of Desert Research Center. All collected samples were transferred quickly to the laboratory, moving soil debris and unhealthy parts, then they were air-dried at lab temperature under shading till constant weight, and finally ground to fine powder and kept carefully to be used for different analyses.

\section{Extraction of Phenolic Compounds}

Fifty $\mathrm{mg}$ of the dried plant material was used. Extraction was performed three times with $2 \mathrm{~mL} 80 \%$ methanol $(\mathrm{MeOH})$ using an overhead shaker and ultrasonic bath. After each extraction step, the samples were centrifuged for twenty minutes at $13.000 \mathrm{rpm}$, $10000 \mathrm{~g}$ and the supernatant was saved. The resulting supernatants were combined and centrifuged again for thirty minutes at $13.000 \mathrm{rpm}$ to remove any suspended particles. The clear supernatant was used for further analysis [22].

\section{Determination of Total Phenolic Content}

Analysis of the total phenol content is based on a colorimetric measurement at $765 \mathrm{~nm}$ [23]. A standard series of gallic acid (GA) was used for quantification. Each sample was measured as technical triplicate. Results were given as GA equivalents (GAE)/g dry weight. Twenty-five $\mu \mathrm{L}$ of extracted sample (1:10 diluted with $\mathrm{H}_{2} \mathrm{O}$ ) was incubated with $125 \mu \mathrm{L}$ of "FolinCiocalteau" phenol reagent (1:10 diluted with water) for eight minutes at room temperature (RT). Exactly $125 \mu \mathrm{L}$ of sodium carbonate $(7.5 \%)$ was added to the well and mixed by pipetting. The mixture was incubated for two hours in the dark. Absorbance was measured at $765 \mathrm{~nm}$ with a microplate reader (BioTek, Winooski, USA). The total phenol content was calculated by the factor estimated with the GA standard series.

\section{Determination of Total Flavonoid Content}

The extraction follows the procedure as described for the determination of total phenol content [22]. Into each well $150 \mu \mathrm{L}$ of deionized water was filled and 25 $\mu \mathrm{L}$ of a sample or one of the catechin hydrate standard solutions were added. Next $10 \mu \mathrm{L}$ of a $3.75 \% \mathrm{NaNO}_{2}$ solution was added, and the plate was gently shaken and afterwards incubated at room temperature for six minutes in darkness. After incubation, $10 \mu \mathrm{L}$ of $\mathrm{AlCl}_{3}$ (10\%) was added, and the plate is again gently shaken and incubated for five minutes at room temperature in the dark. After this step, $50 \mu \mathrm{L}$ of $1 \mathrm{M} \mathrm{NaOH}$ were added and the absorbance at $510 \mathrm{~nm}$ was measured using a microplate reader (BioTek,Winooski, USA).
Identification of Phenolic Compounds by HPLC

HPLC analysis was performed using the HPLC system (Shimadzu; Darmstadt, Germany) consisting of a controller (CBM-20A), two pumps (LC-20AD), a column oven (CTO-20AC) and a photo diode array detector (SPD-M20A). A Vertex Plus column (250 x 4 $\mathrm{mm}, 55 \mu \mathrm{m}$ particle size, packing material ProntoSIL 120-5 C18-H) with pre-column (Knauer, Berlin, Germany) was used for sample separation. Prior to analysis the samples were diluted $1: 2$ in $80 \%$ methanol and $10 \mu \mathrm{L}$ was used. The temperature of the column oven was set to $30^{\circ} \mathrm{C}$. Ammonium acetate $(2 \mathrm{mM})$ was added to eluents of water (A) and methanol (B). Both eluents had a flow rate of $0.8 \mathrm{~mL} \mathrm{~min}^{-1}$. The gradient was applied in the following manner: starting with $10 \%$ $\mathrm{B}$, then switching linearly to $90 \% \mathrm{~B}$ in thirty-five minutes, two minutes of $90 \%$, switching to $10 \% \mathrm{~B}$ in one minute and the subsequent equilibration at $10 \% \mathrm{~B}$ for two minutes. UV/Vis spectra from 190-800 nm were recorded. Components were injected into an AB Sciex Triple TOF mass spectrometer (AB Sciex TripleTOF 4600, Canby, USA) following HPLC separation for identification. A temperature of $600^{\circ} \mathrm{C}$ was used for negative electrospray ionization. The phenolic acid and flavonoid standards for the identification and quantification were prepared in the same way. Peaks were compared by examining retention time and fragmentation pattern using the PeakView (SCIEX) software [24].

\section{Antioxidant Activity}

Free radical scavenging activity $2.5 \mathrm{~mL}$ of different concentrations of ethanolic extracts were added to ethanolic solution of DPPH $(0.3 \mathrm{mM}, 1 \mathrm{~mL})$. After 30 $\mathrm{min}$ at room temperature in dark cabinet, the absorbance (AB) values were measured at $517 \mathrm{~nm}$ on a Unicam UV/Vis spectrophotometer. Ethanol $(1 \mathrm{~mL})$ plus plant extract solution $(2.5 \mathrm{~mL})$ was used as a blank, while DPPH solution plus methanol was used as a control [25]. Percentage of antioxidant activity was calculated from the following equation: DPPH radical scavenging capacity $(\%)=[1-\mathrm{Ab}$ of sample $-\mathrm{Ab}$ of blank $/ \mathrm{Ab}$ of control] 100.)

\section{Antimicrobial Activity \\ Susceptibility Test}

The susceptibility test was performed according to NCCLS recommendations. Screening test regarding the inhibition zone was carried out by the well diffusion method [26]. The inoculum suspension was prepared from colonies grown overnight on an agar plate and inoculated into Mueller-Hinton broth (fungi using malt broth). A sterile swab was immersed in the suspension and used to inoculate Mueller-Hinton agar plates (fungi using malt agar plates). The compounds were dissolved in dimethyl sulfoxide (DMSO) with different concentrations $(10,5,2.5 \mathrm{mg} / \mathrm{ml})$. The inhibition zone was measured around each well after $24 \mathrm{~h}$ at $37^{\circ} \mathrm{C}$. Controls using DMSO were adequately done. The fungal 
and bacterial strains were obtained from the Regional Center for Mycology and Biotechnology (RCMB), AlAzhar University.

\section{Results and Discussion}

Determination of total Flavonoids and total Phenol

According to the data presented in table (1), the percentages of total flavonoids in D. tortuosa, $D$. syrticus, A. graveolens, and Petroselinum crispum were $0.960 \%, 0.962 \%, 0.955 \%$, and $0.975 \%$, respectively. Meanwhile Anethum graveolens had the highest percentage of total phenol $(8.575 \%)$, whereas $D$. tortuosa had the lowest amount $(7.817 \%)$. D. syrticus had $7.983 \%$, and P. crispum had $8.333 \%$ (Table 1 ).

The presence of tested secondary metabolites in the seeds of A. graveolens is in line with earlier reports [14, 27]. Similar results were reported for the presence of tannins, steroids, flavonoids and terpenoids in leaves, stems, roots, in vitro callus and regenerated leaves of $A$. graveolens [28]. Similarly, tests carried out by [29] also showed that, the leaves contained tannins, flavonoids, terpenoids and saponins. Other tests performed by [30] showed the presence of alkaloids, flavonoids, saponins in the seeds. This is comparable to our results, with few exceptions, which may be due to several intrinsic or extrinsic factors including climatic conditions related to the collection area, cultural practices, storage conditions and stages of plant development at harvest time [31]. The results of [32] confirmed the same results that we obtained in this study which showed that $P$. crispum phytochemical screening aerial parts indicated the presence of primary and secondary metabolites, where alkaloid, carbohydrate, phenolic compound, tannins, flavonoids, proteins, amino acids and saponins were detected. The two major phenolic compounds extracted from parsley flakes were identified as apiin and malonyl-apiin [33].

\section{Determination of Flavonoids and Phenolics using HPLC}

Catechin, chlorogenic acid, and rutin were found in all $70 \%$ ethanolic extracts of plants, according to HPLC analysis. Except for A. graveolens, all plants contained apigenin. Caffeic acid was exclusively found in $D$. tortuosa. All extracts were devoid of gallic acid and hesperidin. As stated in table (2), quercetin was found in D. syrticus, and A. graveolens, kampferol was found only in D. syrticus, and ellagic acid was found in $D$. syrticus and $P$. crispum (Table 2). The data obtained are in line with those reported by [34], which revealed that, the highest content of phenolic compounds was found in aboveground part of dill (1399.8 mg GAE/100 g of dray plant material) from Latvia [34]. Also, [35] showed that, in dill sample from Pakistan, the total polyphenols content was $2970 \mathrm{mg} \mathrm{GAE} / 100 \mathrm{~g}$ ). Higher values (19000 mgGAE/100 g) have been reported by [36] in Iranian dill. Parsley is considered as one of the most common culinary herbs consumed globally and one of the richest sources of commonly occurring phenolic aglycone, apigenin. In accordance, [37] found that, apigenin was previously identified from parsley extract. Our findings are in agreement with [38] who did not detect quercetin in the parsley extract. Data of the present study also disagreed with the data obtained by [39] who demonstrated the presence of just two phenolic compounds namely, gallic acid and caffieic acid when parsley aqueous methanolic extract was analysed by HPLC. Flavonoids, phenylpropanoids, terpenoids, unsaturated sterols and coumarins are chemical constituents which have been previously characterized from $D$. tortuosa [40]. In our study we found that, $D$. syrticus had a significant content of flavonoids and this is in line with [41] who showed that, the methanolic extract of $D$. crinitus was found to be richer in flavonoids.

Table (1) Percentages of total Flavonoids and total Phenol in the tested plants.

\begin{tabular}{lcc}
\hline Plant species & Phenol(\%) & Flavonoids (\%) \\
\hline Deverra tortuosa & 7.817 & 0.960 \\
Daucus syrticus & 7.983 & 0.962 \\
Anethum graveolens & 8.575 & 0.955 \\
Petroselinum crispum & 8.333 & 0.975 \\
\hline
\end{tabular}

Table (2) Percentages of Flavonoids and Phenolics using HPLC (mg/mL).

\begin{tabular}{lcccccccc}
\hline $\begin{array}{l}\text { Plant } \\
\text { species }\end{array}$ & Catechin & $\begin{array}{c}\text { Phenolic acids } \\
\text { Chlorogenic } \\
\text { Cacid }\end{array}$ & Caffeic acid & $\begin{array}{c}\text { Ellagic } \\
\text { acid }\end{array}$ & Rutin & Quercetin & $\begin{array}{c}\text { Flavonoids } \\
\text { Kampferol }\end{array}$ & Apigenin \\
\hline $\begin{array}{l}\text { D. tortuosa } \\
\text { D. syrticus }\end{array}$ & 0.50 & 2.02 & 5.94 & ND & 6.29 & ND & ND & 0.20 \\
A. graveolens & 0.005 & 1.02 & ND & 0.17 & 0.57 & 0.22 & 0.10 & 0.16 \\
P. crispum & 0.25 & 19.76 & ND & ND & 3.97 & 0.30 & ND & ND \\
\hline
\end{tabular}

ND: Not detected 


\section{Antimicrobial Activity}

The effect of $70 \%$ ethanol extract of each plant on bacterial and fungal inhibition was investigated. The presence of inhibition zone diameter ( $\mathrm{mm}$ ) was used to determine the antimicrobial activity. The four extracts had no effect on Aspergillus fumigates and Staphylococcus aureus, while the extract of A. graveolens had no effect on Proteus vulgaris, according to the findings in table (3). The extract of D. syrticus produced the best results on Escherichia coli and Proteus vulgaris. The extracts of D. tortuosa and A. graveolens demonstrated the best effects on Bacillus subtilis and Candida albicans, respectively. P. crispum produced the best effect on Bacillus subtilis also.

Shan et al. (2007) [42] reported that, 46 extracts from dietary spices and medicinal herbs exhibited antibacterial activity against foodborne pathogenic bacteria. The methanolic extract of $P$. crispum and Coriandrum sativum stems showed strong antioxidant activities in terms of radical scavenging and the ironinduced linoleic model system [43].

Parsley is known for its antimicrobial [44], and antioxidant [45] effects. In this study, the extract of $P$. crispum showed a good effect on B. subtilis and E. coli (12 \& $8 \mathrm{~mm}$, respectively) and this could be confirmed by the study of [43] who determined the antioxidant and antibacterial effects of parsley leaves and stems on methanol and water extracts. Methanol-derived leaf extracts exhibited significantly greater radicalscavenging activity towards both lipid and water-soluble radicals. Bacterial cell damage might result in significant inhibition of growth of $B$. subtilis and E. coli.

The antibacterial properties of the essential oil fraction (EOF) of A. graveolens against E. faecalis, $K$. pneumoniae, S. aureus, S. epidermidis and S. typhi varied from moderate to weak compared with streptomycin, while E. coli and $P$. aeruginosa were not sensitive to the EOF. On the other hand, the deodorized hot water fraction of $A$. graveolens and the methanol fraction of $A$. graveolens did not exhibit any antibacterial activities against the tested bacteria. The antibacterial activity of the essential oil of $A$. graveolense might be related to carvone, which is the major component according to the findings of [46]. Shahat et al. (2008) [47] reported that, the major component of the Enterolobium contortisiliquum oil was carvone, which could exhibit the growth inhibition of Gram positive bacteria (B. subtilis, B. cereus, S. aureus and Micrococcus luteus) and Gram negative bacteria $(K$. pneumoniae and Serratia marcescencs). In a previous study by [48], the growth rate of E. coli, Streptococcus thermophilus and Lactococcus lactis decreased with increasing concentrations of carvone, which suggests that, it acts by disturbing the metabolic energy status of the bacterial cells.
Parsley is known to have different bioactive phytomolecules such as tocopherol, flavonoids, apiole, phenyl propanoids, furano coumarins, terpenoids and carotenoids [49]. Different bioactive flavonoids i.e. apiin, apigenin, 6-acetylapiin and kaempferol 3-O- $\beta$-Dglucopyranoside were isolated from aerial parts of $P$. crispum [50], whole parts of the plant produce the essential oil particularly its seeds [51]. Myristicin and apiole are the two main components of $P$. crispum essential oil which are responsible for its antioxidant activity [52]. Antimicrobial activity of parsley against wide board of microorganisms was well postulated for its essential oil or different organic solvent extracts [53]. Our findings agreed with those of $[54,55]$ who stated that, the antibacterial activities of parsley against various strains have already been reported for the essential oils of the species, whereas [56] disagreed with our findings, stating that the effectiveness against Mucor species, Aspergillus flavus, and Candida albicans was documented. The natural extracts from this plant contain a variety of phenolic derivatives and essential oils with power inhibittion effect against bacteria [57]. In our results, we noticed that, E. coli and Proteus vulgaris which is a bacterium to negative Gram, showed less sensitivity ( $8 \& 10 \mathrm{~mm}$, respectively) to the action of the parsley extract of the, contrary to bacteria that was Gram positive Bacillus subtilis $(12 \mathrm{~mm})$. This result is supported by the variation of the results by the different composition and the cellular structure of bacteria to Gram positive and Gram negative bacteria, because and according to [58], the Gram negative bacterial cells contain a wall rich in lipids and a double membrane equipped with a died plasmic space. This confers its degree of protection against the constituents of the essential oil. So, we supposed that $E$. coli inhibition requires high concentrations of essential oil.

The findings of Fayed et al. (2021) [59] exhibited that, the EO of $D$. tortuosa had significant antimicrobial potentialities against five Gram-negative bacterial strains Escherichia coli ATCC25922, Listeria monocytogenes ATCC35152, Pseudomonas aeruginosa ATCC15442, Salmonella typhi ATCC1408, and Streptococcus epidermis ATCC12228, three Gram-negative bacterial strains Bacillus subtilis ATCC6633, Entrobacter cloeoae ATCC13047, and Staphylococcus aureus ATCC23235, and one fungi (Candida albicans ATCC10321). These promising results were consistent with our findings.

Daucus syrticus had an effect on Gram (+) and Gram (-) bacteria but had no effect on fungi. These results are in accordance with the result of [60] who recorded that, the methanolic extract of Daucus syrticus had great activity against Gram (-), Gram (+) bacteria but our result disagreed with him because he recoded that, the extract had a low activity against yeast and fungi. He also noticed that, luteolin exhibited activity 
against $A$. niger and E. coli, while Diosmetin-7-Oglucoside gave activity against $B$. subtillis only, and this low activity may be due to lake of free $\mathrm{OH}$ groups. Cho et al. (2008) [19] demonstrated that, the Daucus carota had both antibacterial and antifungal activities. Abd Alla et al. (2013) [60] cleared that, the volatile oil of $D$. syrticus exhibited the highest activity against $B$. subtilis and the fatty acids against $E$. coli; the petroleum ether extract had a moderate activity against Gram negative and Gram positive bacteria and yeasts, but had no effect on $A$. niger, and these results agree with ours, and also they noticed that the acetone-insoluble extract had a remarkable effect against Gram negative and Gram positive bacteria, yeasts and fungi used and the fatty acid fraction had high activity against Gram negative and Gram positive bacteria, with a moderate effect on yeasts and fungi.

Table (3) Antibacterial and Antifungal Activity of Plants.

\begin{tabular}{|c|c|c|c|c|c|}
\hline \multirow[b]{2}{*}{ Microorganism } & \multicolumn{4}{|c|}{ Plant } & \multirow[b]{2}{*}{ Control } \\
\hline & $\begin{array}{l}\text { Deverra } \\
\text { tortuosa }\end{array}$ & $\begin{array}{l}\text { Daucus } \\
\text { syrticus }\end{array}$ & $\begin{array}{l}\text { Anethum } \\
\text { graveolens }\end{array}$ & $\begin{array}{c}\text { Petroselinum } \\
\text { crispum }\end{array}$ & \\
\hline & \multicolumn{5}{|c|}{ inhibition zone diameter $(\mathrm{mm})$} \\
\hline \multicolumn{6}{|c|}{$\begin{array}{l}\text { inhibition zone diameter (mm) } \\
\text { Fungi }\end{array}$} \\
\hline $\begin{array}{l}\text { Aspergillus fumigates } \\
\text { (RCMB 002008) }\end{array}$ & ND & ND & ND & ND & 17 \\
\hline Candida albicans & 8 & 13 & 14 & 9 & 20 \\
\hline \multicolumn{6}{|c|}{ Gram positive bateria } \\
\hline $\begin{array}{l}\text { Staphylococcus aureus } \\
\text { (ATCC 25923) }\end{array}$ & ND & ND & ND & ND & 24 \\
\hline Bacillus subtilis & 20 & 15 & 15 & 12 & 26 \\
\hline RCMB 015 (1) NRRL B-543 & & & & & \\
\hline \multicolumn{6}{|c|}{ Gram neagative bateria } \\
\hline $\begin{array}{l}\text { Escherichia coli } \\
\text { (ATCC 25922) }\end{array}$ & 9 & 10 & 9 & 8 & 30 \\
\hline $\begin{array}{l}\text { Proteus vulgaris } \\
\text { RCMB } 004 \text { (1) ATCC } 13315\end{array}$ & 11 & 12 & ND & 10 & 25 \\
\hline
\end{tabular}

ND: Not detected.

Table (4) Antioxidant Activity of the Tested Plants (\%).

\begin{tabular}{lcccccccccc}
\hline $\begin{array}{l}\text { Plant } \\
\text { species }\end{array}$ & \multicolumn{4}{c}{ Chloroform $(\mathbf{p p m})$} & \multicolumn{4}{c}{ Ethyl acetate (ppm) } \\
& $\mathbf{1 0 0 0}$ & $\mathbf{8 0 0}$ & $\mathbf{6 0 0}$ & $\mathbf{4 0 0}$ & $\mathbf{2 0 0}$ & $\mathbf{1 0 0 0}$ & $\mathbf{8 0 0}$ & $\mathbf{6 0 0}$ & $\mathbf{4 0 0}$ & $\mathbf{2 0 0}$ \\
\hline D. tortuosa & 22.13 & 35.69 & 35.76 & 11.55 & 20.38 & 43.15 & 5.91 & 6.10 & 9.86 & 22.71 \\
D.syrticus & 14.34 & 14.73 & 2.40 & 22.52 & 22.13 & 49.19 & 4.35 & 18.56 & 16.22 & 25.05 \\
A.graveolens & 13.69 & 26.35 & 30.24 & 6.16 & 24.08 & 48.02 & 22.26 & 72.87 & 61 & 70.15 \\
P. crispum & 1.82 & 16.22 & 10.19 & 0.45 & 25.44 & 14.54 & 46.40 & 78.33 & 11.36 & 32.77 \\
\hline
\end{tabular}

Table (4) Continued .

\begin{tabular}{lcccccccccc}
\hline & \multicolumn{4}{c}{ Alcohol (70\%) } & $(\mathbf{p p m})$ & \multicolumn{5}{c}{ Water (ppm) } \\
& $\mathbf{1 0 0 0}$ & $\mathbf{8 0 0}$ & $\mathbf{6 0 0}$ & $\mathbf{4 0 0}$ & $\mathbf{2 0 0}$ & $\mathbf{1 0 0 0}$ & $\mathbf{8 0 0}$ & $\mathbf{6 0 0}$ & $\mathbf{4 0 0}$ & $\mathbf{2 0 0}$ \\
\hline D. tortuosa & 7.33 & 34.91 & 25.37 & 6.10 & 33.94 & 56.52 & 13.30 & 61.97 & 53.60 & 42.12 \\
D.syrticus & 69.05 & 78.72 & 46.40 & 7.46 & 3.18 & 51.65 & 59.83 & 96.04 & 60.61 & 1.82 \\
A.graveolens & 62.04 & 10.58 & 4.35 & 12.91 & 69.37 & 24.98 & 69.95 & 83 & 7.27 & 2.79 \\
P. crispum & 14.54 & 43.48 & 7.27 & 14.86 & 3.05 & 20.51 & 3.18 & 14.93 & 9.21 & 7.33 \\
\hline
\end{tabular}




\section{Antioxidant Activity}

In the present study, the antioxidant activities of different extracts of the tested plants were investigated at different concentrations (Table 4). The highest antioxidant activities of both $D$. tortuosa and $D$. syrticus were observed at $600 \mathrm{ppm}$ for chloroform, $1000 \mathrm{ppm}$ for ethyl acetate, $800 \mathrm{ppm}$ for $70 \%$ alcohol, and $600 \mathrm{ppm}$ for water. Meanwhile, the highest levels of antioxidant activities of $A$. graveolens were reported at $400 \mathrm{ppm}$ for chloroform, $600 \mathrm{ppm}$ for ethyl acetate, $200 \mathrm{ppm}$ for $70 \%$ alcohol, and $800 \mathrm{ppm}$ for water. The highest antioxidant activities of $P$. crispum were noticed at $200 \mathrm{ppm}$ for chloroform, $600 \mathrm{ppm}$ for ethyl acetate, $800 \mathrm{ppm}$ for $70 \%$ alcohol, and $1000 \mathrm{ppm}$ for water. Such increased antioxidant activities might be due to the presence of higher concentrations of phenolic compounds (including phenols and flavonoids).

In this regard, the extracts of $D$. tortuosa have been previously shown to exhibit high antioxidants activities $\left(\mathrm{IC}_{50}=64.8102 \mu \mathrm{g} / \mathrm{mL}\right)$.

In addition, dill leaf and seed extracts were used for comparison. In all assays, the flower extract showed higher antioxidant activity than the leaf and seed extracts. With regard to various fractions of the flower extract, the sequence for antioxidant activity was ethyl acetate fraction > ethanol fraction > original flower extract $>\mathrm{n}$-hexane fraction. Phenols including flavonoids and proanthocyanidins might be responsible for antioxidant abilities of the flower extract. Chlorogenic acid, myricetin, and 3,3', $4^{\prime}, 5,7$ pentahydoxyflavan $\quad(4 \rightarrow 8)-\quad 3,3^{\prime}, 4^{\prime}, 5,7-$ pentahydoxyflavan were observed to be the major phenolic acids, flavonoids, and proanthocyanidin, respectively, in the dill flower extract [61].

Using the 2,2,1-diphenyl-1-picrylhydrazyl (DPPH) radical scavenging and potassium ferricyanide-ferric chloride assay, [62] reported that, essential oils extracted from parsley flowers by hydrodistillation exhibited antioxidant activity at 500, 1000,2000 and $5000 \mathrm{mg} / \mathrm{mL}$ with the highest concentration exhibiting inhibition of DPPH radical at $64.28 \%$ and ferric reducing power of $0.93 \mathrm{mmol} / \mathrm{L}$ Trolox. [63] by means of the ferric reducing ability of plasma (FRAP), lipid peroxidation and spectrophotometry (high performance liquid chromatography (HPLC) and bicinchoninic acid kit assay reported that, aqueous extracts of $P$. crispum leaves and its isolated flavonoids (quercetin and kaempferol) at a concentration of $5 \mathrm{mg} / \mathrm{g}$ significantly $(\mathrm{p}<0.001)$ increased the total antioxidant capacity and decreased malondialdehyde concentration in hyperuricemic rats. Leaf and stem aqueous and methanol extracts of $P$. crispum have been identified to possess antioxidant activity in vitro via the DPPH radical-scavenging, ion-chelating and hydroxyl radical assays [43].
Methanol-derived leaf extracts exhibited significantly greater radical-scavenging activity towards both lipid-and water-soluble radicals, which was attributed to the total phenolic content. Ferrous ion-chelating activity was significantly greater in the stem methanol extracts. Using the Folin-Ciocalteu assay, [64] reported that wheat pasta fortified with powdered P. crispum leaves [1 to $4 \%$ (w/w)] exhibited antioxidant activity in vitro. Essential oil from seeds of $P$. crispum exhibited antioxidant activity using betacarotene bleaching, DPPH free radical scavenging and $\mathrm{Fe}^{2+}$ - metal chelating assays. The $\mathrm{EC}_{50}$ values of the bcarotene bleaching assay and DPPH free radical scavenging assay of the crude $P$. crispum oil dissolved in methanol were 5.12 and $80.21 \mathrm{mg} / \mathrm{mL}$, respectively [52].

Other species of Daucus, such as D. gracilis and D. carota, have shown high anti-oxidative activities that might be related to their phenolic content [65].

\section{Conclusion}

Based on the above results, it could be concluded that the tested plants have moderate antimicrobial, as well as potent antioxidant activities, which consequently could support their nutritive and health promoting values.

\section{Acknowledgment}

The authors would like to thank Dr. Waleed Gamal El-Din Fahmy, Head of Micro-analysis Lab., Desert Research Center, Egypt for his helping with the instruments, and to Dr. Omran Nasser Ghaly, Head of Taxonomy Unit, Desert Research Center, Egypt for identification and authentication of the studied plants.

\section{Conflict of interest}

No conflict of interest associated with this work.

\section{Authors' contribution}

The authors declare that, this work was done by the authors named in tis manuscript liabilities pertaining to claims relating to the content of this article will be borne by them. 


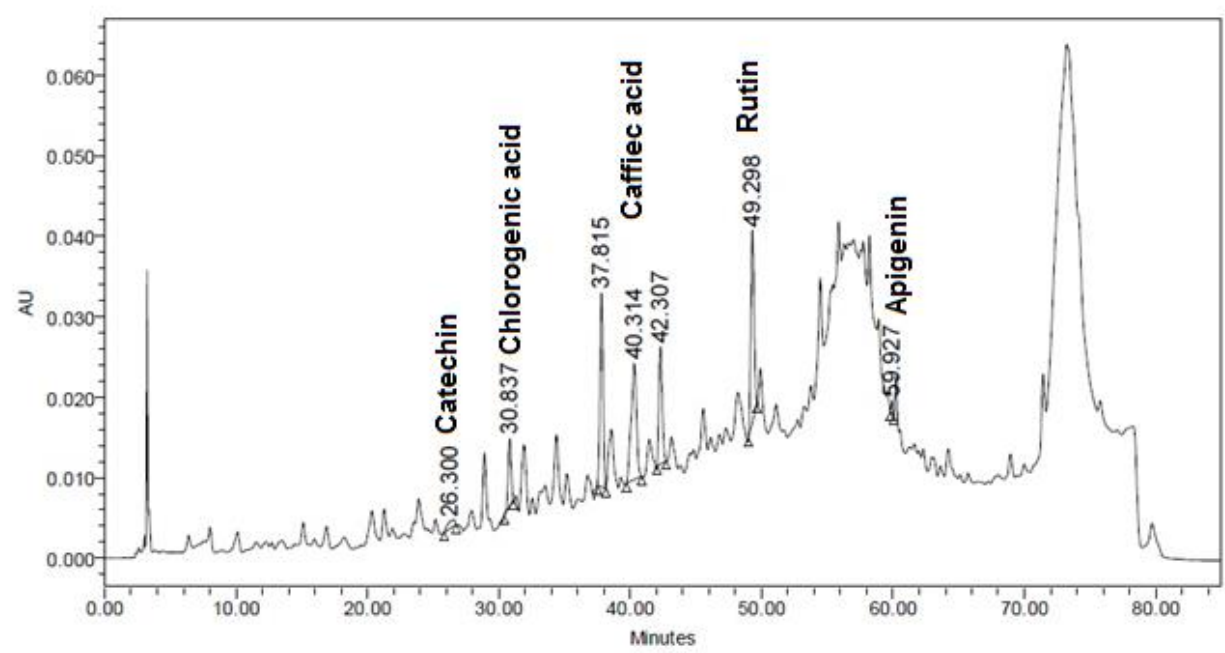

Fig. (1) HPLC of total Phenolics and Flavonoid compounds of D. tortuosa.

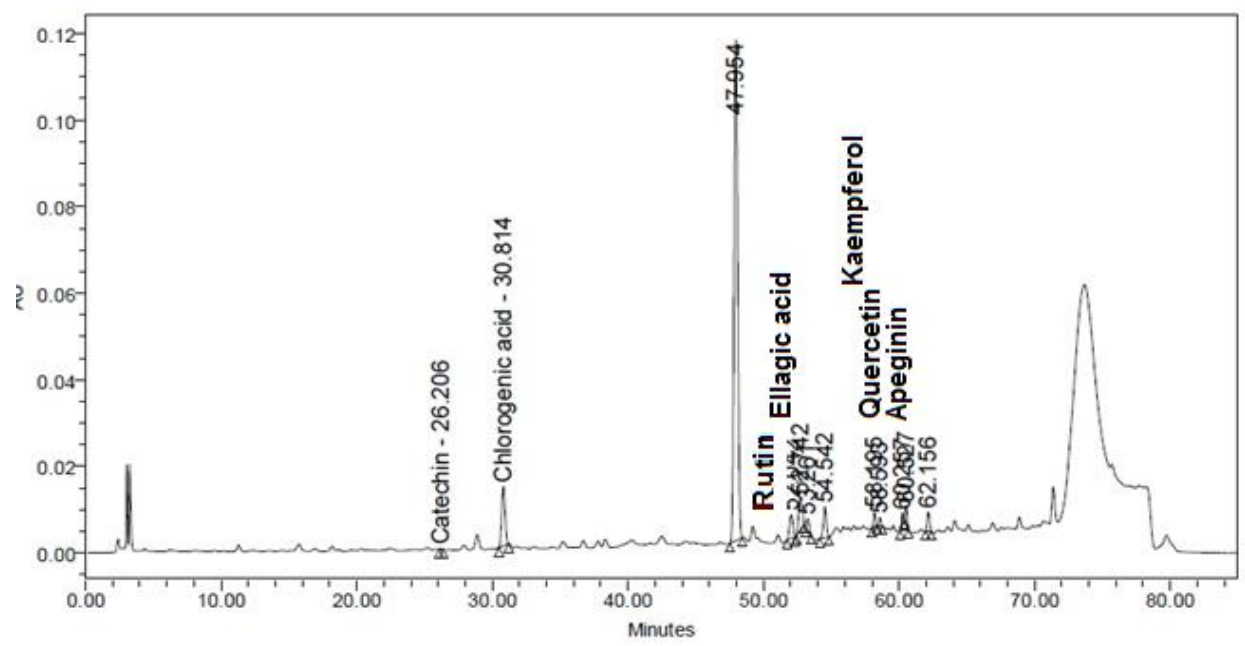

Fig. (2) HPLC of Phenolics and Flavonoids of D. syrticus.

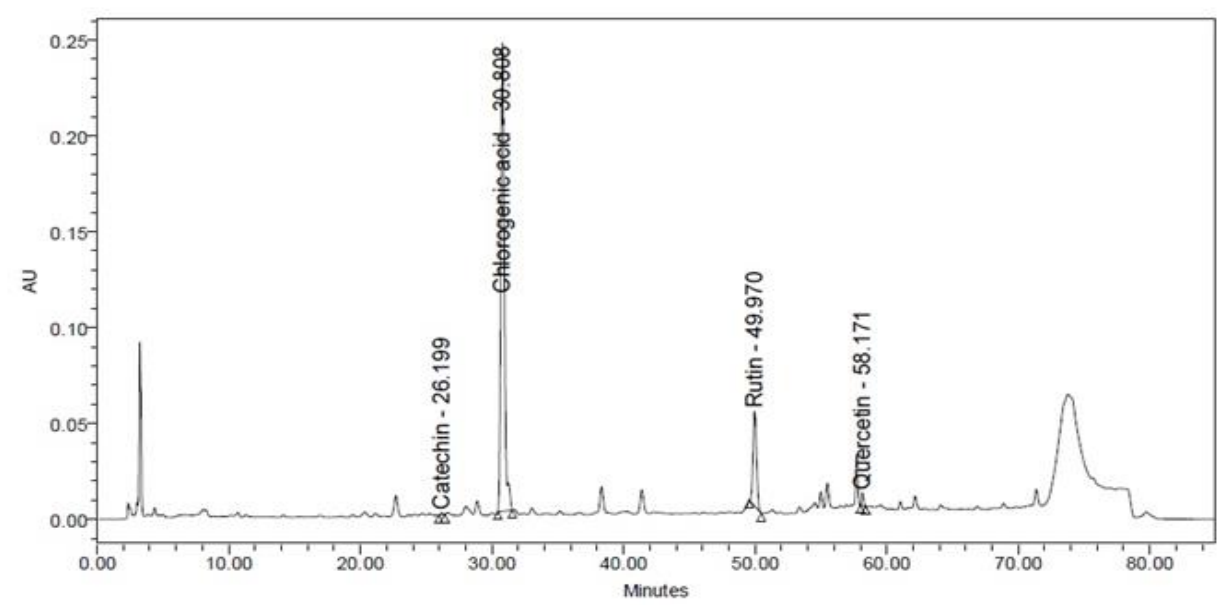

Fig. (3) HPLC of Phenolics and Flavonoid compounds of A. graveolens. 


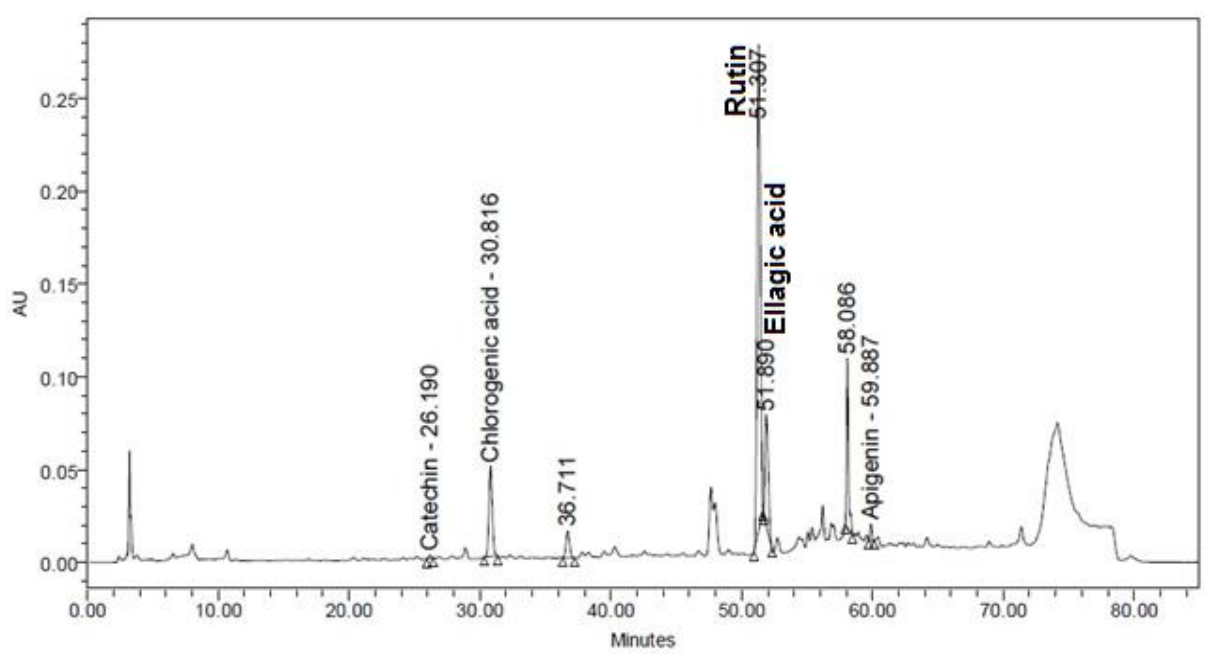

Fig. (4) HPLC of total Phenolics and Flavonoid compounds of P. crispum.

\section{References}

[1] M.Vasudevan, M.Parle, Pharmacological evidence for the potential of Daucus carota in the management of cognitive dysfunctions. Biol. Pharm. Bull.vol.29,pp.1154-1161, 2006

[2] R.Gupta, P.SK, Senna In: Chadha KL, Gupta R editors. Advances in Horticulture Medicinal and Aromatic Plants.vol.11,1995.

[3] P.A.G.Santos, A.C.Figueiredo, P.M.L.Lourenço, J.G.Barroso, L.G.Pedro, M.M.Oliveira, J.Schripsema, S.G.Deans, J.J.C.Scheffer, Hairy root cultures of Anethum graveolens (dill): establishment, growth, timecourse study of their essential oil and its comparison with parent plant oils. Biotechnol. Lett.vol.24,pp.1031-1036,2002.

[4] J.Słupski, Z.Lisiewska, W.Kmiecik, Contents of macro and microelements in fresh and frozen dill (Anethum graveolens L.). Food Chem.vol.91,pp.737-743,2005.

[5] R.Nair, S.Chanda, Antibacterial activities of some medicinal plants of the western region of India. Turkish J. Biol.vol.31,pp.231-236,2007.

[6] P.J.Delaquis, K.Stanich, B.Girard, G.Mazza, Antimicrobial activity of individual and mixed fractions of dill, cilantro, coriander and eucalyptus essential oils. Int. J. Food Microbiol.vol.74,pp.101-109,2002.

[7] R.Yazdanparast, M.Alavi, Antihyperlipidaemic and antihypercholesterolaemic effects of Anethum graveolens leaves after the removal of furocoumarins. Cytobios.vol.105,pp.185191,2001.

[8] S.H.F.Al-Ma'adhedi, Phytochemical screening, estimation of some heavy metals concentrations, and specific extraction of bioactive components from Iraqi Anethum graveolens L. Seeds and Studying their Antibacterial. Al-Anbar J. Vet. Sci.vol.5,pp.2836,2012.

[9] G.Singh, S.Maurya, M.P.De Lampasona, C.Catalan, Chemical constituents, antimicrobial investigations, and antioxidative potentials of Anethum graveolens L. essential oil and acetone extract: Part 52. J. Food Sci.vol.70,pp.M208M215,2005.

[10] H.A.Soliman, N.A.Eltablawy, M.S.Hamed, The ameliorative effect of Petroselinum crispum (Parsley) on some diabetes complications. J. Med. Plants Stud.vol.3,pp.92-100,2015.

[11] M.Blumenthal, A.Goldberg, J.Brinckmann, Herbal medicine. Expanded commission E monographs.; Integrative Medicine Communications, 2000.

[12] N.G.Bisset, M.Wichtl, Herbal drugs. Stuttgart: Medpharm,1994.

[13]L.Boulos, Flora of Egypt, 2 (GeraniaceaeBoraginaceae) Cairo. AL-Hadara Pub,pp.352,2000.

[14] G.H.Mahran, M.S.Ahmed, A.A.Seida, A.A.Amarquaye, A phytochemical investigation of Pituranthos tortuosus (Desf.) Benth and Hook. Bull. Fac. Pharmacy, Cairo Univ.vol.27,pp.87-89,1989.

[15] K.Boukef, H.R.Souissi, G.Balansard, Contribution à l'étude des plantes utilisées en médecine traditionnelle tunisienne. Pl Méd Phyto.vol.16,pp.260-279,1982.

[16] M.A.Pathak, Fitzpatrick, T.B. Sunlight and man. In Proceedings of the International Conference on Photosensitization and Photoprotection (1972: Tokyo); University of Tokyo Press, 1974. 
[17]C.Sáenz Laín, Research on Daucus L. Umbelliferae). An. Jard Bot Madri.vol.37,pp.481-534,1981.

[18]H.Teubert, G.Wünscher, K.Herrmann, Flavonols and flavones of vegetables. VIII. Flavones of carrot leaves (author's transl). Zeitschrift fur Leb. Und-forsch.vol.165,pp.147$150,1977$.

[19] W.Cho, J.Choi, K.Lee, M.Chung, Y.Pyun, Antimicrobial activity of torilin isolated from Torilis japonica fruit against Bacillus subtilis. J. Food Sci.vol.73,pp.M37-M46,2008.

[20] M.S.Kim, Y.M.Lee, E.Moon, S.E.Kim, J.J.Lee, K.Kim, Anti-angiogenic activity of torilin, a sesquiterpene compound isolated from Torilis japonica. Int. J. cancer.vol.87,pp.269275,2000.

[21] N.Radulović, N.Đorđević, Z.Stojanović-Radić, Volatiles of the Balkan endemic Daucus guttatus ssp. zahariadii and cultivated and wildgrowing D. carota-A comparison study. Food Chem.vol.125,pp.35-43,2011.

[22] V.Dewanto, X.Wu, K.K.Adom, R.H.Liu, Thermal processing enhances the nutritional value of tomatoes by increasing total antioxidant activity. J. Agric. Food Chem.vol.50,pp.3010-3014,2002.

[23] M. Abdel-Mawgoud, F. G. Khedr, and E. I. Mohammed. "Phenolic Compounds, Antioxidant and Antibacterial Activities of Rhus flexicaulis Baker." Jord J. Biol. Sci. vol.12, pp 17 - 21, 2019.

[24] M.S.Almuhayawi, S.K.Al Jaouni, S.M.Almuhayawi, S.Selim, M.AbdelMawgoud, Elevated $\mathrm{CO}_{2}$ improves the nutritive value, antibacterial, anti-inflammatory, antioxidant and hypocholestecolemic activities of lemongrass sprouts. Food Chem, 2021.

[25] V.Katalinic, M.Milos, T.Kulisic, M.Jukic, Screening of 70 medicinal plant extracts for antioxidant capacity and total phenols. Food Chem.vol.94,pp.550-557,2006.

[26] M.S.Almuhayawi, M.Abdel-Mawgoud, S. K. Al Jaouni, S. M. Almuhayawi, M. H. Alruhaili, S. Selim, \& H. AbdElgawad. Bacterial Endophytes as a Promising Approach to Enhance the Growth and Accumulation of Bioactive Metabolites of Three Species of Chenopodium Sprouts. Plants, vol.10(12), pp.2745, 2021.

[27] B.S.Fazly Bazzaz, G.Haririzadeh, S.A.Imami, M.H.Rashed, Survey of Iranian plants for alkaloids, flavonoids, saponins, and tannins [Khorasan Province]. Int. J. Pharmacogn.vol.35,pp.17-30,1997.

[28] S.Jana, G.S.Shekhawat, Anethum graveolens: An Indian traditional medicinal herb and spice. Pharmacogn. Rev.vol.4, pp.179,2010.
[29] G.J.Kaur, D.S.Arora, Bioactive potential of Anethum graveolens, Foeniculum vulgare and Trachyspermum ammi belonging to the family Umbelliferae-Current status. J. Med. Plants Res.vol.4,pp.87-94,2010.

[30] H.O.Edeoga, D.E.Okwu, B.O.Mbaebie, Phytochemical constituents of some Nigerian medicinal plants. African J. Biotechnol.vol.4,pp.685-688,2005.

[31]H.Falleh, R.Ksouri, K.Chaieb, N.KarrayBouraoui, N.Trabelsi, M.Boulaaba, C.Abdelly, Phenolic composition of Cynara cardunculus $L$. organs, and their biological activities. C. R. Biol.vol.331, pp372-379,2008.

[32] A.M.H.Al-Haadi, S.S.Al Rahbi, M.S.Akhtar, S.Said, A.Weli, Q.Al Riyami, Phytochemical screening, antibacterial and cytotoxic activities of Petroselinum crispum leaves grown in Oman. Iran. J. Pharm. Sci.vol.9,pp.61-65,2013.

[33]D.L.Luthria, Influence of experimental conditions on the extraction of phenolic compounds from parsley (Petroselinum crispum) flakes using a pressurized liquid extractor. Food Chem.vol.107,pp.745752,2008 .

[34] M.Stankevičius, I.Akuņeca, I.Jãkobsone, A.Maruška, Analysis of phenolic compounds and radical scavenging activities of spice plants extracts. Maisto Chem. ir Technol.vol.44,pp.85-91,2010.

[35] A.Akhtar, A.A.Deshmukh, A.V.Bhonsle, P.M.Kshirsagar, M.A.Kolekar, In vitro antibacterial activity of Pimpinella anisum fruit extracts against some pathogenic bacteria. Vet. World .vol.1,pp.272-274,2008.

[36] E.A.Oshaghi, I.Khodadadi, H.Tavilani, M.T.Goodarzi, Effect of dill tablet (Anethum graveolens L.) on antioxidant status and biochemical factors on carbon tetrachlorideinduced liver damage on rat. Int. J. Appl. Basic Med. Res.vol.6,pp.111,2016.

[37]M.Stan, M.L.S oran, C.Varodi, I.Lung, Extraction and identification of flavonoids from parsley extracts by HPLC analysis. In Proceedings of the AIP Conference Proceedings; American Institute of Physics.vol.1425,pp.50-52,2012.

[38] G.L.Hostetler, R.A.Ralston, S.J.Schwartz, Flavones: Food sources, bioavailability, metabolism, and bioactivity. Adv. Nutr.vol.8, pp.423-435,2017.

[39] M.Muchuweti, Phenolic composition and antioxidant properties of some spices $\mathrm{M}$. Muchuweti, E. Kativu, CH Mupure, C. Chidewe, AR Ndhlala and MAN Benhura Department of Biochemistry, University of 
Zimbabwe. Am. J. Food Technol.vol.2,pp.414420,2007.

[40] M.Azzazi, M.Afifi, O.Tammam, A.Sheikh Alsouk, Chemical composition and antifungal activity of the essential oil from Deverra tortuosa against phytopathogenic fungi. Swift J Agric Res.vol.1,pp.28-32,2015.

[41] A.Bendiabdellah, M.E.A.Dib, N.Meliani, N.Djabou, H.Allali, B.Tabti, Preliminary phytochemical screening and antioxidant activities of solvent extracts from Daucus crinitus Desf., from Algeria. J Appl Pharm Sci .vol.2,pp.92-95,2012.

[42] B.Shan, Y.-Z.Cai, J.D.Brooks, H.Corke, The in vitro antibacterial activity of dietary spice and medicinal herb extracts. Int. J. Food Microbiol.vol.117,pp.112-119,2007.

[43] P.Y.Y.Wong, D.D.Kitts, Studies on the dual antioxidant and antibacterial properties of parsley (Petroselinum crispum) and cilantro (Coriandrum sativum) extracts. Food Chem.vol.97,pp.505-515,2006.

[44] S.Z.Fejes, A.Blazovics, E.Lemberkovics, G.Petri, E.Szöke, A.Kery, Free radical scavenging and membrane protective effects of methanol extracts from Anthriscus cerefolium L.(Hoffm.) and Petroselinum crispum (Mill.) Nym. ex AW Hill. Phyther. Res.vol.14,pp.362$365,2000$.

[45] S.E.Nielsen, J.F.Young, B.Daneshvar, S.T.Lauridsen, P.Knuthsen, B.Sandström, L.O.Dragsted, Effect of parsley (Petroselinum crispum) intake on urinary apigenin excretion, blood antioxidant enzymes and biomarkers for oxidative stress in human subjects. Br. J. Nutr.vol.81, pp.447-455,1999.

[46] K.Tanruean, K.Kaewnarin, N.Rakariyatham, Antibacterial and antioxidant activities of Anethum graveolens L. dried fruit extracts. Chiang Mai J. Sci.vol.41,pp.649-660,2014.

[47] A.A.Shahat, G.El-Barouty, R.A.Hassan, F.M.Hammouda, F.H.Abdel-Rahman, M.A.Saleh, Chemical composition and antimicrobial activities of the essential oil from the seeds of Enterolobium contortisiliquum (leguminosae). J. Environ. Sci. Heal. Part B.vol.43,pp.519-525,2008.

[48] K.Oosterhaven, B.Poolman, E.J.Smid, Scarvone as a natural potato sprout inhibiting, fungistatic and bacteristatic compound. Ind. Crop. Prod.vol.1,pp. 23-31,1995.

[49]T.Tunali, A.Yarat, R.Yanardag, F.Özçelik, Ö.Özsoy, G.Ergenekon, N.Emekli, Effect of parsley (Petroselinum crispum) on the skin of STZ induced diabetic rats. Phyther. Res. An Int. J. Devoted to Pharmacol. Toxicol. Eval. Nat. Prod. Deriv.vol.13,pp.138-141,1999.
[50]D.Gadi, M.Bnouham, M.Aziz, A.Ziyyat, A.Legssyer, A.Bruel, M.Berrabah, C.Legrand, F.Fauvel-Lafeve, H.Mekhfi, Flavonoids purified from parsley inhibit human blood platelet aggregation and adhesion to collagen under flow. J. Complement. Integr. Med.vol.9,2012.

[51] J.Bruneton, Pharmacognosy, Phytochemistry, Medicinal Plants.; Lavoisier publishing, 1995.

[52]H.Zhang, F.Chen, X.Wang, H.-Y.Yao, Evaluation of antioxidant activity of parsley (Petroselinum crispum) essential oil and identification of its antioxidant constituents. Food Res. Int.vol.39,pp.833-839,2006.

[53] G.A.Linde, Z.C.Gazim, B.K.Cardoso, L.F.Jorge, V.Tešević, J.Glamočlija, M.Soković, N.B.Colauto, Antifungal and antibacterial activities of Petroselinum crispum essential oil. Genet. Mol. Res.vol.15,2016.

[54] M.-L.Soran, M.Stan, I.Lung, M.R.C.Truşcă, Microwave field effect on polyphenolic compounds from aromatic plants. J. Sustain. Dev. Energy, Water Environ. Syst.vol.4,pp.4855,2016 .

[55]H.Farah, E.Elbadrawy, A.A.Al-Atoom, Evaluation of anti-oxidant and antimicrobial activities of ethanolic extracts of parsley (Petroselinum erispum) and coriander (Coriandrum sativum) plants grown in saudi arabia. Int J.vol.3, pp.1244-1255,2015.

[56] K.Abdu, D.G.Hauwa, In vitro evaluation of the antioxidant and antimicrobial activity of leaf extracts of Petroselinum cripsum (Parsley). Chem Search J.vol.10,pp.25-29,2019.

[57] O.Nawel, H.Ahmed, Phytochemical analysis and antimicrobial bioactivity of the Algerian parsley essential oil (Petroselinum crispum). African J. Microbiol. Res.vol.8, pp.1157$1169,2014$.

[58] J.-P.Larpent, Manuel pratique de microbiologie, 1985.

[59]E.M.Fayed, A.M.Abd-EIGawad, A.I.Elshamy, E.F.El-Halawany, Y.A.EI-Amier, Essential oil of Deverra tortuosa aerial parts: detailed chemical profile, allelopathic, antimicrobial, and antioxidant activities. Chem. Biodivers.vol.18, 2021.

[60]F.M.Abd Alla, K.A.Abdelshafeek, A.M.El-soll, W.M.ELsayed, Volatile oils, lipid constitutes and the antimicrobial activity of Daucus syrticus growing in Libya. J. Arab Soc. Med. Res. vol.8,pp.96,2013.

[61] Y.S.Shyu, J.T.Lin, Y.T.Chang, C.J.Chiang, D.J.Yang, Evaluation of antioxidant ability of ethanolic extract from dill (Anethum graveolens L.) flower. Food Chem.vol.115,pp.515521,2009 . 
[62] I.Marín, E.Sayas-Barberá, M.Viuda-Martos, C.Navarro, E.Sendra, Chemical composition, antioxidant and antimicrobial activity of essential oils from organic fennel, parsley, and lavender from Spain. Foods. vol. 5,pp.18,2016.

[63]F.Haidari, S.A.Keshavarz, M.M.Shahi, S.A.Mahboob, M.R.Rashidi, Effects of parsley (Petroselinum crispum) and its flavonol constituents, kaempferol and quercetin, on serum uric acid levels, biomarkers of oxidative stress and liver xanthine oxidoreductase aactivity inoxonate-induced hyperuricemic rats. Iran. J. Pharm. Res.vol.10,pp.811-819,2011.
[64] Ł.Sęczyk, M.Świeca, U.Gawlik-Dziki, Changes of antioxidant potential of pasta fortified with parsley (Petroselinum Crispum Mill.) leaves in the light of protein-phenolics interactions. Acta Sci. Pol. Technol. Aliment. vol.14, pp2936,2015.

[65] M.El Kolli, H.Laouer, H.El Kolli, S.Akkal, F.Sahli, Chemical analysis, antimicrobial and anti-oxidative properties of Daucus gracilis essential oil and its mechanism of action. Asian Pac. J. Trop. Biomed.vol.6,pp.8-15,2016. 